\title{
PENGARUH REBUSAN DAUN SIRIH MERAH (Piper crotatum) TERHADAP PERTUMBUHAN BAKTERI STAPHYLOCOCCUS AUREUS
}

\author{
Yodong1, Tri Wiyatini' ${ }^{2}$, Lanny Sunarjo ${ }^{3}$
}

\begin{abstract}
Since a hundreds of years ago Red Betel Leaf (Piper crotatum) has been known in Indonesia as traditional medicine. Red betel Leaf contains chemical agents as such as flavonoid, polevenoland, karvakro that has antibacterial, antioxidant, antiseptic, and anti inflamatory, and essential oil that can reduce pain in the periodontal tissues. Purpose of the study is to the termine the inhibition effect of red betel leaf against Staphylococcus aureus growth.

This study using quasi experiment because had no control group or comparison group. Design of study is with a random sample which boil the number of Red Betel Leaf and devide into there concentration of $20 \%, 25 \%$ and $30 \%$.

Study result of the showed that there is an influence of the concentration of red betel leaf as staphylococcus aureus growth resistor. Red betel leaf decoction has and influence on the concentration of the staphylococcus aureus with $20 \%$, of the average total inhibition of $10.3 \mathrm{~mm}$, a concentration of $25 \%$ of the average total inhibition of $12.5 \mathrm{~mm}$. Red betel leaf concentration of $30 \%$ is the concentration of the most inflential in inhibiting staphylococcus aureus, as it shows the avarage total bacterial inhibition that most other concentration.
\end{abstract}

Key words : Red Betel Leaf (Piper crotatum), Staphylococcus aureus.

1,2,3) Dosen Jurusan Keperawatan Gigi Poltekkes Kemenkes Semarang

\section{PENDAHULUAN}

Di Indonesia telah dikenal pengobatan non formal (tradisional). Sejak ratusan tahun yang lalu, nenek moyang kita telah memanfaatkan tanaman sebagai upaya penyembuhan dalam mengobati berbagai penyakit, hal tersebut sejalan dengan bunyi pada Pasal 104 ayat (2) dan Pasal 105 ayat (2) Undang-undang Republik Indonesia Nomor 36 Tahun 2009 tentang Kesehatan, bahwa Penggunaan obat dan obat tradisional harus dilakukan secara rasional, sediaan farmasi yang berupa obat tradisional dan kosmetik serta alat kesehatan harus memenuhi standar dan/atau persyaratan yang ditentukan.

Tanaman sirih merah tumbuh merambat dengan bentuk daun menyerupai hati dan bertangkai, yang tumbuh berselang-seling dari batangnya. Sementara itu, ciri khas yang bisa ditemukan pada tanaman ini adalah penampakan daunnya yang berwarna merah keperakan dan mengilap. Di dalam sirih merah terkandung bahan-bahan kimia seperti senyawa flavanoid dan polevenolad memiliki sifat antibakteri, antioksidan, antidiabetik, antiseptic, dan antiinflamasi. Karvakrol yang bersifat disinfektan dan antijamur, dapat digunakan sebagai obat antiseptic untuk bau mulut dan keputihan. Tanin untuk mengobati sakit perut, Adapun manfaat lain dari kandungan senyawa pada daun sirih merah, seperti karvakrol yang bersifat disinfektan dan antijamur, dapat digunakan sebagai obat antiseptik untuk bau mulut dan keputihan, sedangkan eugenol bermanfaat untuk mengurangi rasa sakit pada gigi dengan cara merebus daun sirih merah (Kurniawan. 2013).

Air rebusan daun sirih merah sering digunakan oleh masyarakat sebagai obat kumur. Air rebusan sirih merah mengandung anti bakteri dan anti jamur pada rongga mulut, sehingga dapat 
mencegah bau mulut yang tidak sedap selain itu dapat pula mencegah proses terjadinya lubang pada gigi manusia. Munculnya sirih merah yang kini menjadi fenomena, selain cantik dipandang mata sebagai tanaman hias yang eksotik, juga bermanfaat sebagai tanaman obat pembasmi berbagai jenis penyakit bagi masyarakat (Sudewo, 2005).

Bakteri berasal dari kata "bakterion" (bahasa yunani) yang berarti tongkat atau batang. Sekarang nama bakteri dipakai untuk menyebut sekelompok mikroorganisme yang bersel satu, tidak berklorofil, berbiak dengan pembelahan diri, serta demikian kecilnya hanya tampak dengan mikroskop. Bakteri merupakan kata latin bacterium adalah kelompok raksasa dari organisme hidup yang sangat kecil (mikroskopik) dan kebanyakan uniselluler (bersel tunggal) dengan struktur sel yang relatif sederhana tanpa inti sel, tulang dan bagian tubuh lain seperti mitokondria dan kloroplas. Bakteri merupakan prokariota sebab memiliki sel yang lebih sederhana (Mahata, 2008).

Bakteri Staphylococcus aureus merupakan penyebab penyakit infeksi yang ditandai oleh adanya lubang yang berisi nanah (pus) dalam jaringan yang sakit. Dental abses artinya abses yang terbentuk di dalam jaringan periapikal atau periodontal karena infeksi gigi atau perluasan dari ganggren pulpa. Abses yang terbentuk merusak jaringan periapikal, tulang alveolus, tulang rahang terus menembus kulit pipi. Abses gigi terjadi ketika terinfeksi bakteri dan menyebar ke rongga mulut atau dalam gigi, Penyebabnya adalah bakteri yang merupakan flora normal dalam mulut. Yaitu bakteri coccus aerob gram positif, coccus anaerob gram positif dan batang anaerob gram negatif. Bakteri terdapat dalam plak yang berisi sisa makanan dan kombinasi dengan air liur.

Bakteri coccus aerob gram positif, coccus anaerob gram positif dan batang anaerob gram negatif. Bakteri terdapat dalam plak yang berisi sisa makanan dan kombinasi dengan air liur. Bakteri-bakteri tersebut dapat menyebabkan karies dentin, gingivitis, dan periodontitis. Jika mencapai jaringan yang lebih dalam melalui nekrosis pulpa dan pocket periodontal. Abses dental ini terjadi akibat adanya faktor iritasi seperti plak, kalkulus, karies dentin, invasi bakteri (Staphylococcus aureus, Streptococcus, Haemophilis influenzae), impaksi makanan atau trauma jaringan. Keadaan ini dapat menyebabkan kerusakan tulang alveolar sehingga terjadi gigi goyang (Mustari,2010).

\section{METODE PENELITIAN}

Penelitian merupakan penelitian kuantitatif dengan metode experimental research yang bertujuan untuk mengetahui suatu gejala atau pengaruh yang timbul sebagai akibat dari adanya perlakuan tertentu. Penelitian ini merupakan quasi experiment (Notoadmojo, 2010). Penelitian ini dilakukan di laboratorium Mikrobiologi Jurusan keperawatan gigi poltekkes Kemenkes Semarang.

Rancangan Penelitian :

$(\mathrm{X} 1, \mathrm{X} 2, \mathrm{X} 3)$ : Perlakuan dengan pengujian larutan daun sirih merah dengan konsentrasi 20\%, 25\%,30\%.

$(0-A, 0-B, 0-C)$ : Pengamatan dan pengukuran radius area daya hambat $(\mathrm{mm})$.

Air rebusan daun sirih merah dibuat dengan konsentrasi $20 \%, \quad 25 \%, \quad 30 \%$ untuk menghambat pertumbuhan bakteri Staphylococcus aureus. Rebusan daun sirih merah adalah suatu larutan yang diproses antara daun sirih merah dan air kemudian dipanaskan di atas hot plate.

Cara pembuatan larutan :

$$
(\% \mathrm{~b} / \mathrm{b})=\frac{\mathrm{g} \text { zat terlarut } \times 100 \%}{\mathrm{~g} \text { zat terlarut }+\mathrm{g} \text { pelarut }}(\text { Yazid, 2005) }
$$

Konsentrasi $20 \%=\frac{20 \mathrm{~g} \times 100 \%=20 \%}{20 \mathrm{~g}+80 \mathrm{ml}}$ Jadi 20 gram daun sirih merah dilarutkan ke dalam $80 \mathrm{ml}$ air. 
Konsentrasi $25 \%=\frac{25 \mathrm{~g} \times 100 \%=25 \%}{25 \mathrm{~g}+75 \mathrm{ml}}$

Jadi 25 gram daun sirih merah dilarutkan ke dalam $75 \mathrm{ml}$ air.

Konsentrasi $30 \%=\frac{30 \mathrm{~g} \times 100 \%=30 \%}{30 \mathrm{~g}+75 \mathrm{ml}}$

Jadi 30 gram daun sirih merah dilarutkan ke dalam $70 \mathrm{ml}$ air.

Instrumen yang digunakan : Elemeyer, hot plate, Tmbangan Tabung reaksi,rak tabung, cawan petri, bunsen, pinset, korek api , beaker glass, incubator, autoclave, karet gelang, Jangka sorong, kapas dan lidi, kertas paper disk, jarum ose.

Dalam pengumpulan data dilakukan observasi terstruktur dengan melakukan pengkodean dengan mengklasifikasikan data dengan kode-kode atau karakteristik tertentu untuk mempermudah pengolahan data, dengan kode sebagai berikut :

$\mathrm{D} 1$ = diameter $\mathrm{I}=$ vertikal

D2 = diameter II = horizontal

D3 = diameter III = diagonal I

D4 $=$ diameter IV = diagonal II

Dalam penelitian ini data yang diperoleh dari hasil pengukuran dan perhitungan, diolah dalam bentuk tabulasi, kemudian dalam menganalisa data, peneliti menggunakan jenis analisa deskriptif kuantitatif yaitu untuk mendapatkan gambaran tentang pengaruh perbedaan larutan rebusan daun sirih merah sebagai daya hambat pertumbuhan bakteri Staphylococcus aureus.

\section{HASIL DAN PEMBAHASAN}

Hasil penelitian yang telah dilakukan di Laboratorium Mikrobiologi Jurusan Keperawatan Gigi Semarang pada tangaal 20 - 21 Mei 2014 dengan judul “Uji Daya Hambat Rebusan Daun Sirih Merah (Piper crotatum) Terhadap Pertumbuhan Bakteri Staphylococcus aureus" dapat dilihat pada tabel sebagai berikut:
Tabel 1. Daya Hambat Larutan Rebusan Daun Sirih Merah dengan Konsentrasi 20\%, 25\%, 30\% pada Pengulangan I

\begin{tabular}{ccccc}
\hline \multirow{2}{*}{ Pengulangan $\begin{array}{c}\text { Daya } \\
\text { Hambat }\end{array}$} & \multicolumn{3}{c}{ Larutan Rebusan } \\
Daun Sirih Merah
\end{tabular}

Tabel 1 menunjukkan bahwa pengulangan ke-I dengan konsentrasi 20\% larutan rebusan daun sirih merah mempunyai rata-rata total daya hambat terhadap bakteri Staphylococcus aureus sebesar 11,5mm, konsentrasi 30\% mempunyai rata-rata total daya hambat terhadap bakteri Staphylococcus aureus sebesar $12 \mathrm{~mm}$. Dari tabel di atas daya hambat tertinggi yaitu rata-rata total daya hambat tertinggi yaitu rata-rata total daya hambat rebusan daun sirih merah dengan konsentrasi $25 \%$ mempunyai daya hambat terhadap bakteri Staphylococcus aureus sebesar $12,25 \mathrm{~mm}$ dikategorikan respon daya hambat lemah.

Tabel 2. Daya Hambat Larutan Rebusan Daun Sirih Merah dengan Konsentrasi 20\%, 25\%, 30\% pada Pengulangan II

\begin{tabular}{|c|c|c|c|c|}
\hline \multirow[t]{2}{*}{ Pengulangan } & \multirow{2}{*}{$\begin{array}{c}\text { Daya } \\
\text { Hambat }\end{array}$} & \multicolumn{3}{|c|}{$\begin{array}{l}\text { Larutan Rebusan } \\
\text { Daun Sirih Merah }\end{array}$} \\
\hline & & $20 \%$ & $25 \%$ & $30 \%$ \\
\hline \multirow{4}{*}{ II } & D1 & $10 \mathrm{~mm}$ & $13 \mathrm{~mm}$ & $13 \mathrm{~mm}$ \\
\hline & D2 & $10 \mathrm{~mm}$ & $9 \mathrm{~mm}$ & $12 \mathrm{~mm}$ \\
\hline & D3 & $10 \mathrm{~mm}$ & $10 \mathrm{~mm}$ & $12 \mathrm{~mm}$ \\
\hline & D4 & $9,75 \mathrm{~mm}$ & $10 \mathrm{~mm}$ & $10 \mathrm{~mm}$ \\
\hline \multicolumn{2}{|c|}{ Rata-rata } & $9,75 \mathrm{~mm}$ & $10,5 \mathrm{~mm}$ & $11,75 \mathrm{~mm}$ \\
\hline
\end{tabular}

Tabel 2 hasil pemeriksaan yang dilakukan pengulangan ke-II dengan konsentrasi 20\% larutan rebusan daun sirih merah mempunyai rata-rata total daya hambat terhadap bakteri Staphylococcus aureus sebesar 9,75mm, konsentrasi 25\% mempunyai rata-rata total daya hambat terhadap bakteri Staphylococcus aureus sebesar $10,5 \mathrm{~mm}$. Dari tabel diatas daya hambat tertinggi yaitu rata-rata total daya hambat rebusan daun sirih merah dengan konsentrasi 30\% mempunyai daya hambat 
terhadap bakteri Staphylococcus aureus sebesar $11,75 \mathrm{~mm}$ dikategorikan respon daya hambat lemah.

Tabel 3. Daya Hambat Larutan Rebusan Daun Sirih Merah dengan Konsentrasi 20\%, 25\%, 30\% pada Pengulangan III

\begin{tabular}{ccccc}
\hline \multirow{2}{*}{ Pengulangan $\begin{array}{c}\text { Daya } \\
\text { Hambat }\end{array}$} & \multicolumn{3}{c}{ Larutan Rebusan } \\
\cline { 2 - 5 } & $20 \%$ & $25 \%$ & $30 \%$ \\
\hline \multirow{4}{*}{ III } & D1 & $9 \mathrm{~mm}$ & $12 \mathrm{~mm}$ & $15 \mathrm{~mm}$ \\
& D2 & $10 \mathrm{~mm}$ & $11 \mathrm{~mm}$ & $14 \mathrm{~mm}$ \\
& D3 & $9 \mathrm{~mm}$ & $11 \mathrm{~mm}$ & $12 \mathrm{~mm}$ \\
& D4 & $11 \mathrm{~mm}$ & $10 \mathrm{~mm}$ & $14 \mathrm{~mm}$ \\
\hline \multicolumn{2}{c}{ Rata-rata } & $9,75 \mathrm{~mm}$ & $11 \mathrm{~mm}$ & $13,75 \mathrm{~mm}$ \\
\hline
\end{tabular}

Tabel 3 menunjukkan bahwa pengulangan ke-III dengan konsentrasi 20\% larutan rebusan daun sirih merah mempunyai rata-rata total daya hambat terhadap bakteri Staphylococcus aureus sebesar 9,75mm, konsentrasi 25\% mempunyai rata-rata total daya hambat terhadap bakteri Staphylococcus aureus sebesar $11 \mathrm{~mm}$. Dari tabel diatas daya hambat tertinggi rata-rata total daya hambat rebusan daun sirih merah dengan konsentrasi $30 \%$ mempunyai daya hambat terhadap bakteri Staphylococcus aureus sebesar $13,75 \mathrm{~mm}$ dikategorikan respon daya hambat lemah.

Tabel 4. Rata-Rata Total Daya Hambat Larutan Rebusan Daun Sirih Merah dengan Konsentrasi $20 \%$, 25\%, dan 30\% pada Pengulangan I, II, dan III

\begin{tabular}{ccccc}
\hline & \multicolumn{3}{c}{ Zona Hambat (mm) } & $\begin{array}{c}\text { Rata- } \\
\text { Konsentrasi }\end{array}$ \\
& $\begin{array}{c}\text { Pengulangan } \\
\text { I }\end{array}$ & Pengulangan & $\begin{array}{c}\text { Pengulangan } \\
\text { rata }\end{array}$ \\
\hline $20 \%$ & 11,5 & 9,75 & 9,75 & 10,3 \\
$25 \%$ & 12,5 & 10,5 & 11 & 11,25 \\
$30 \%$ & 12 & 11,75 & 13,75 & 12,5 \\
\hline
\end{tabular}

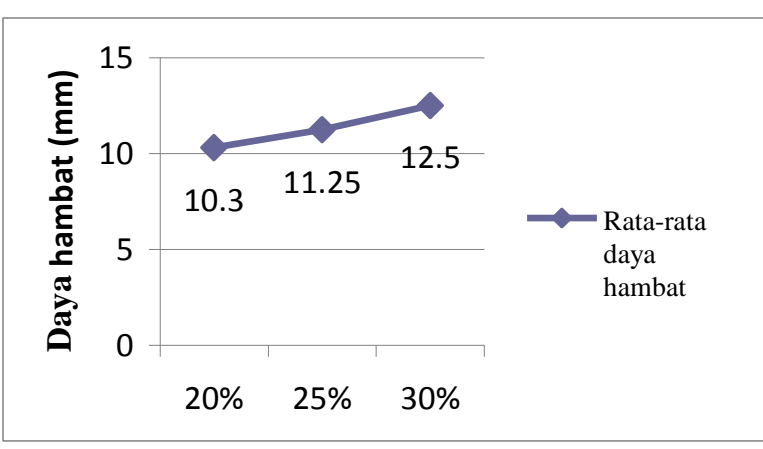

Gambar 1. Nilai Rata-rata Total Daya Hambat Rebusan Daun Sirih Merah (Piper crotatum) Terhadap Pertumbuhan Bakteri Staphylococcus aureus dengan Konsentrasi 20\%, 25\%, 30\%.

Tabel 4 dan Gambar 1 menunjukkan bahwa semakin tinggi konsentrasi rebusan daun sirih merah semakin besar diameter zona daya hambatnya. Sedangkan semakin rendah konsentrasi rebusan daun sirih merah semakin kecil diameter zona daya hambatnya. Hal ini dapat dilihat pada bentuk grafik yang semakin tinggi konsentrasinya, yaitu pada konsentrasi 30\% grafiknya paling tinggi dan konsentrasi $20 \%$ paling rendah.

\section{KESIMPULAN}

Hasil dari penelitian yang telah dilakukan pada tanggal 20 - 21 Mei 2014 di Laboratorium Mikrobiologi Jurusan Keperawatan Gigi Semarang sebagai berikut :

1. Adanya pengaruh perbedaan konsetrasi rebusan daun sirih merah sebagai penghambat pertumbuhan bakteri Staphylococcus aureus, yaitu semakin besar konsentrasi rebusan daun sirih merah maka kandungan zat atau senyawa aktif yang terkandung didalamnya juga semakin banyak, maka daya hambat terhadap pertumbuhan bakteri Staphylococcus aureus semakin besar.

2. Rebusan daun sirih merah konsentrasi $20 \%$ memiliki pengaruh terhadap bakteri Staphylococcus aureus karena memiliki rata-rata total daya hambat sebesar $10,3 \mathrm{~mm}$. 
3. Rebusan daun sirih merah konsentrasi $25 \%$ memiliki pengaruh terhadap bakteri Staphylococcus aureus karena memiliki rata-rata total daya hambat sebesar $11,25 \mathrm{~mm}$.

4. Rebusan daun sirih merah konsentrasi $30 \%$ memiliki pengaruh terhadap bakteri Staphylococcus aureus karena memiliki rata-rata total daya hambat sebesar $12,5 \mathrm{~mm}$.

\section{DAFTAR PUSTAKA}

Agoes, 1993, Farmakologi dan Obat Tradisional, Kapita, Jakarta.

Jawetz, E. , Melnick, J.L, Adelberg, E.A., 2004, Mikrobiologi Kedokteran, Kedokteran EGC, Jakarta.

Kurniawan, S, 2013, Obat Ajaib Sirih Merah dan Daun Kelor, Buku Biru, Jogyakarta.

Mahata, Dira Gana , 2008, Rahasia Bakteri, PT Elex Media Komputindo, Jakarta.

Manson, J.D., Eley, B.M., 1993. Buku Ajar Periodonti, Hipokrates, Jakarta.

Mustari, S. , 2010, Gigi dan Mulut.

http://mustarisujadisuso.blogspot.com/201 $\underline{0 / 06 / 1 . h t m l}$ (diakses pada tanggal 3 Februari 2014).

Notoadmojo, S, 2010, Metodologi Penelitian Kesehatan, PT.Rineka Cipta, Jakarta.

Pratama, Septa, 2012, Sekilas Tentang Sirih Merah.

http:// belajarherbal.wordpress.com/catego ry/tanaman-obat/ (diakses pada tanggal 2 Februari 2014).

Ramadhan, 2010, Serba Serbi Kesehatan Gigi dan Mulut, Bukuné, Jakarta.
Srikandi, F, 1992, Mikrobiologi Pengolahan Pangan, Pusat Antara IPB, Bogor.

Sudewo, B, 2005, Basmi Penyakit dengan Sirih Merah, Agro Media Pustaka, Jakarta.

Syahruracman, A, dkk, 1993, Buku Ajar Mikrobiologi Kedokteran, Binarupa Aksara, Jakarta.

Tanjaya, J., Elza, A.I., 2011, IL-1 $\beta$ Genetic Polimorphism in Menopause

Women as Periodontal Disease Risk Factor, Journal of Dentistry Indonesia (diakses pada tanggal 19 April 2014).

Undang-undang RI Nomor 36 Tahun 2009, Tentang Kesehatan.

Yazid, E., 2005, Kimia Fisika untuk Paramedis, ANDI, Yogyakarta. 